\begin{tabular}{|l|l|l||}
\hline \multicolumn{2}{|c|}{ PublisherInfo } \\
\hline \hline PublisherName & $:$ & BioMed Central \\
\hline \hline PublisherLocation & $:$ & London \\
\hline \hline PublisherImprintName & $:$ & BioMed Central \\
\hline \hline
\end{tabular}

\title{
Anchoring nuclei to the cytoskeleton
}

\begin{tabular}{|l|l|l||}
\hline \multicolumn{2}{|c|}{ ArticleInfo } \\
\hline \hline ArticleID & $:$ & 4607 \\
\hline \hline ArticleDOI & $:$ & $10.1186 /$ gb-spotlight-20021011-01 \\
\hline \hline ArticleCitationID & $:$ & spotlight-20021011-01 \\
\hline \hline ArticleSequenceNumber & $:$ & 273 \\
\hline \hline ArticleCategory & $:$ & Research news \\
\hline \hline ArticleFirstPage & $:$ & 1 \\
\hline \hline ArticleLastPage & $:$ & 2 \\
\hline \hline & & RegistrationDate : 2002-10-11 \\
ArticleHistory & $:$ & OnlineDate $\quad$ 2002-10-11 \\
\hline \hline ArticleCopyright & $:$ & BioMed Central Ltd2002 \\
\hline \hline ArticleGrants & $:$ & \\
\hline \hline ArticleContext & $:$ & 130593311 \\
\hline \hline
\end{tabular}




\section{Jonathan B Weitzman}

Email: jonathanweitzman@hotmail.com

The adult Caenorhabditis elegans worm is covered by four large syncytial hypodermal cells that contain over 100 nuclei evenly spaced throughout each syncytium. Mutations in the anc-1 or unc-84 genes cause the Anc phenotype, in which these nuclei either float freely within the cytoplasm or are grouped together. In the October 11 Science, Daniel Starr and Min Han describe characterization of the ANC-1 protein (Science 2002, 298:406-409). They cloned the anc-1 gene, which encodes a large protein containing mostly predicted coiled regions. The carboxyl terminus contains a 'KASH' domain, which is found in the Drosophila Klarsicht protein and mammalian Syne ('synaptic nuclei expressed') proteins. The amino terminus contains an actin-binding domain similar to that found in the dystrophin-related protein Msp-300 and in Syne. Immunostaining with antibodies against ANC-1 revealed that localization in the nuclear periphery is disrupted in unc- 84 mutants. Overexpression of a carboxy-terminal fragment of ANC-1 caused a nuclear anchorage defect, while overexpression of high levels of the ANC-1 amino terminus caused a weak Anc phenotype (and Anc-1 mutations also affected mitochondrial position). The ANC-1 and UNC-84 proteins thus provide a molecular link between nuclei and the actin cytoskeleton.

\section{References}

1. Post-embryonic cell lineages of the nematode, Caenorhabditis elegans

2. Science, [http://www.sciencemag.org] 